\title{
SERIAL ACID-BASE DETERMINATIONS IN NORMAL PREMATURE AND FULL-TERM INFANTS DURING THE FIRST 72 HOURS OF LIFE
}

\author{
BY \\ A. F. MALAN,* A. EVANS, and H. DE V. HEESE \\ From the Neonatal Respiratory Unit, Department of Child Health, University of Cape Town
}

(RECEIVED FOR PUBLICATION APRIL 5, 1965)

Considerable interest and research is centred on the acid-base homeostasis and on its disturbances in newborn infants. Most reports have concerned the acid-base status at birth and the changes during the first few hours of life (Oliver, Demis, and Bates, 1961 ; Weisbrot, James, Prince, Holaday, and Apgar, 1958; Fischer and Toussaint, 1963). Several authors have published values for normal infants at different ages (Reardon, Graham, Wilson, Baumann, Tsao, and Murayama, 1950; Graham and Wilson, 1954; Reardon, Baumann, and Haddad, 1960; Prod'hom, Levison, Cherry, Drorbaugh, Hubbell, and Smith, 1964; Kildeberg, 1964a, b), but only Reardon et al. (1960) have made a serial survey beyond the first 24 hours. It therefore seemed worth while to study the acid-base status on the same infants serially at predetermined times over a period of 72 hours. No such published data are available for premature infants. The opportunity also presented itself to re-evaluate the role of $p \mathrm{H}$ and $\mathrm{PCO}_{2}$ in infants with a respiratory frequency over $60 / \mathrm{min}$. but without respiratory distress (Branning, 1942; Prod'hom et al., 1964.

\section{Material and Methods}

An unselected group of premature and full-term infants was studied in the Peninsula Maternity Hospital. The total number of infants was 36 , of whom 20 were premature and 16 were full term. The series of estimations was largely completed on 17 of the premature and all the full-term infants. However, as only normal and healthy infants were to be considered, 3 premature babies who developed respiratory distress were excluded. Seven children were discharged between 48-72 hours and their final readings were, therefore, not obtained. The majority of the group studied were normal vertex deliveries, with 6 caesarean sections and 2 breech extrac-

* C.S.I.R. Senior Bursar, Department of Child Health, University of Cape Town. tions, of which equal numbers were premature and full term. The decision as to maturity was made on birth weight alone. The average premature birth weight was $2.25 \mathrm{~kg}$. and for full-term infants it was $3.09 \mathrm{~kg}$. The premature group was not further subdivided because of the small number of cases below $2.0 \mathrm{~kg}$. Premature babies were starved for the first 24 hours. They were then given two $5 \%$ dextrose water feeds followed by halfstrength expressed breast milk (EBM). The strength of EBM was increased to $75 \%$ on the 3rd day. Full-term infants were given one or two $5 \%$ dextrose feeds at about 12 hours and then taken to the mothers for breast feeding. If the mother was not able to breast feed, e.g. after caesarean section, the infant then also received halfstrength EBM which was increased to $75 \%$ on the 3 rd day. In 15 premature and 6 full-term infants the respiratory rate was recorded every half-hour for the first 18 hours.

Arterialized capillary blood was collected from each infant at 2, 4, 6, 12, 24, 48, and 72 hours of age. Blood samples were taken from heel stabs after warming the foot for 15 minutes (Gambino, 1961). 224 acid-base values were immediately determined by means of the Astrup method (Siggaard Andersen, Engel, Jørgensen and Astrup, 1960). The $p \mathrm{H}$ and $\mathrm{PCO}_{2}$ were corrected for the temperature of the patient (Rosenthal, 1948; Siggaard Andersen, 1963): this was of importance, as some premature infants had subnormal temperatures. Care was taken to avoid crying before and during the procedure and we were successful on all but 12 of the 224 occasions. The collection of the blood and the determinations were carried out by two of the authors. Throughout the study there was good correlation between the findings of the two operators. Very good blood flow was obtained from these infants compared with experience in ill infants suffering from respiratory distress. Gandy, Grann, Cunningham, Adamsons, and James (1964) have drawn attention to this finding and to the necessity for warming the foot.

In all our calculations we used the standard chart and nomogram for adults according to Siggaard Andersen (1963) whose terminology has been adopted here. 
TABLE 1

SUMMARY OF BLOOD VALUES AT VARIOUS AGES IN PREMATURE AND FULL-TERM INFANTS

\begin{tabular}{|c|c|c|c|c|c|c|c|c|c|c|}
\hline & & & & \multirow{2}{*}{$\begin{array}{l}\text { Age } \\
\text { (hr.) }\end{array}$} & \multicolumn{3}{|c|}{ Premature } & \multicolumn{3}{|c|}{ Full-term } \\
\hline & & & & & Mean & $\begin{array}{l}\text { Standard } \\
\text { Deviation }\end{array}$ & Range & Mean & $\begin{array}{l}\text { Standard } \\
\text { Deviation }\end{array}$ & Range \\
\hline$p \mathrm{H}$. & $\cdots$ & $\cdots$ & $\cdots$ & $\begin{array}{r}2 \\
4 \\
6 \\
12 \\
24 \\
48 \\
72\end{array}$ & $\begin{array}{l}7 \cdot 33 \\
7 \cdot 35 \\
7 \cdot 36 \\
7 \cdot 38 \\
7 \cdot 39 \\
7 \cdot 37 \\
7 \cdot 37\end{array}$ & $\begin{array}{l}0.06 \\
0.04 \\
0.04 \\
0.03 \\
0.04 \\
0.05 \\
0.05\end{array}$ & $\begin{array}{l}7 \cdot 27-7 \cdot 42 \\
7 \cdot 28-7 \cdot 42 \\
7 \cdot 30-7 \cdot 42 \\
7 \cdot 33-7 \cdot 44 \\
7 \cdot 33-7 \cdot 48 \\
7 \cdot 29-7 \cdot 46 \\
7 \cdot 28-7 \cdot 45\end{array}$ & $\begin{array}{l}7 \cdot 34 \\
7 \cdot 38 \\
7 \cdot 38 \\
7 \cdot 40 \\
7 \cdot 41 \\
7 \cdot 42 \\
7 \cdot 42\end{array}$ & $\begin{array}{l}0.06 \\
0.04 \\
0.04 \\
0.03 \\
0.04 \\
0.05 \\
0.04\end{array}$ & $\begin{array}{l}7 \cdot 26-7 \cdot 43 \\
7 \cdot 33-7 \cdot 46 \\
7 \cdot 31-7 \cdot 47 \\
7 \cdot 33-7 \cdot 46 \\
7 \cdot 32-7 \cdot 48 \\
7 \cdot 31-7 \cdot 50 \\
7 \cdot 32-7 \cdot 48\end{array}$ \\
\hline $\mathrm{PCO}_{2}(\mathrm{~mm} . \mathrm{Hg})$ & $\cdots$ & $\cdots$ & $\cdots$ & $\begin{array}{r}2 \\
4 \\
6 \\
12 \\
24 \\
48 \\
72\end{array}$ & $\begin{array}{l}42 \cdot 8 \\
43 \cdot 4 \\
40 \cdot 9 \\
38 \cdot 4 \\
35 \cdot 8 \\
39 \cdot 5 \\
36 \cdot 8\end{array}$ & $\begin{array}{l}6 \cdot 8 \\
8 \cdot 2 \\
9 \cdot 6 \\
6 \cdot 4 \\
4 \cdot 0 \\
6 \cdot 1 \\
5 \cdot 2\end{array}$ & $\begin{array}{l}31 \cdot 7-52 \cdot 0 \\
31 \cdot 7-58 \cdot 5 \\
29 \cdot 5-60 \cdot 5 \\
27 \cdot 0-50 \cdot 2 \\
27 \cdot 6-43 \cdot 0 \\
33 \cdot 0-57 \cdot 0 \\
29 \cdot 0-45 \cdot 0\end{array}$ & $\begin{array}{l}41 \cdot 4 \\
36 \cdot 7 \\
36 \cdot 5 \\
36 \cdot 6 \\
34 \cdot 9 \\
34 \cdot 0 \\
35 \cdot 5\end{array}$ & $\begin{array}{l}8 \cdot 8 \\
5 \cdot 3 \\
3 \cdot 6 \\
3 \cdot 3 \\
4 \cdot 0 \\
4 \cdot 5 \\
5 \cdot 4\end{array}$ & $\begin{array}{l}24 \cdot 5-60 \cdot 0 \\
24 \cdot 3-45 \cdot 7 \\
27 \cdot 5-42 \cdot 0 \\
31 \cdot 7-43 \cdot 0 \\
28 \cdot 5-43 \cdot 0 \\
27 \cdot 0-41 \cdot 5 \\
25 \cdot 0-46 \cdot 0\end{array}$ \\
\hline \multicolumn{3}{|c|}{ Base excess (mEq/1.) } & $\cdots$ & $\begin{array}{r}2 \\
4 \\
6 \\
12 \\
24 \\
48 \\
72\end{array}$ & $\begin{array}{l}-3 \cdot 7 \\
-2 \cdot 3 \\
-2 \cdot 1 \\
-2 \cdot 3 \\
-2 \cdot 6 \\
-2 \cdot 7 \\
-3 \cdot 3\end{array}$ & $\begin{array}{l}2 \cdot 9 \\
2 \cdot 6 \\
3 \cdot 0 \\
1 \cdot 8 \\
1 \cdot 8 \\
1 \cdot 2 \\
2 \cdot 9\end{array}$ & $\begin{array}{l}-8 \cdot 5+2.1 \\
-6.6+2.9 \\
-8 \cdot 6+4 \cdot 2 \\
-6 \cdot 1+0.3 \\
-7.40 \\
-7 \cdot 5+0.6 \\
-9.6-0.5\end{array}$ & $\begin{array}{l}-3 \cdot 8 \\
-2 \cdot 5 \\
-2 \cdot 5 \\
-1 \cdot 4 \\
-1 \cdot 4 \\
-1 \cdot 2 \\
-0.8\end{array}$ & $\begin{array}{l}2.4 \\
1.6 \\
1.8 \\
1.8 \\
1.8 \\
1.7 \\
2.4\end{array}$ & $\begin{array}{l}-8 \cdot 7+0 \cdot 9 \\
-5 \cdot 9+0 \cdot 9 \\
-5 \cdot 8+2 \cdot 2 \\
-4 \cdot 5+4 \cdot 0 \\
-4 \cdot 3+3 \cdot 7 \\
-5 \cdot 3+2 \cdot 0 \\
-4 \cdot 8+3 \cdot 1\end{array}$ \\
\hline \multicolumn{2}{|c|}{ Buffer base (mEq/l.) } & $\cdots$ & $\cdots$ & $\begin{array}{r}2 \\
4 \\
6 \\
12 \\
24 \\
48 \\
72\end{array}$ & $\begin{array}{l}46 \cdot 1 \\
47 \cdot 8 \\
48 \cdot 3 \\
46 \cdot 7 \\
46 \cdot 6 \\
46 \cdot 2 \\
46 \cdot 5\end{array}$ & $\begin{array}{l}2 \cdot 7 \\
3 \cdot 0 \\
3 \cdot 5 \\
2 \cdot 7 \\
2 \cdot 7 \\
2 \cdot 8 \\
3 \cdot 3\end{array}$ & $\begin{array}{l}43 \cdot 2-51 \cdot 8 \\
44 \cdot 0-53 \cdot 2 \\
40 \cdot 5-53 \cdot 2 \\
41 \cdot 1-50 \cdot 3 \\
40 \cdot 8-50 \cdot 3 \\
41 \cdot 8-51 \cdot 0 \\
40 \cdot 6-50 \cdot 2\end{array}$ & $\begin{array}{l}46 \cdot 6 \\
47 \cdot 5 \\
47 \cdot 1 \\
47 \cdot 6 \\
47 \cdot 6 \\
47 \cdot 8 \\
49 \cdot 0\end{array}$ & $\begin{array}{l}3 \cdot 0 \\
1 \cdot 8 \\
2 \cdot 9 \\
2 \cdot 6 \\
2 \cdot 7 \\
3 \cdot 2 \\
3 \cdot 3\end{array}$ & $\begin{array}{l}42 \cdot 5-51 \cdot 9 \\
45 \cdot 0-51 \cdot 2 \\
43 \cdot 2-51 \cdot 0 \\
44 \cdot 4-53 \cdot 0 \\
43 \cdot 8-55 \cdot 3 \\
39 \cdot 6-51 \cdot 5 \\
42 \cdot 5-54 \cdot 0\end{array}$ \\
\hline \multicolumn{3}{|c|}{ Standard $\mathrm{HCO}_{3}^{-}(\mathrm{mEq} / \mathrm{l})}$. & $\cdots$ & $\begin{array}{r}2 \\
4 \\
6 \\
12 \\
24 \\
48 \\
72 \\
\end{array}$ & $\begin{array}{l}21 \cdot 2 \\
22 \cdot 2 \\
22 \cdot 5 \\
22 \cdot 1 \\
21 \cdot 9 \\
21 \cdot 9 \\
21 \cdot 4\end{array}$ & $\begin{array}{l}1 \cdot 8 \\
2 \cdot 2 \\
1 \cdot 4 \\
1 \cdot 6 \\
1 \cdot 6 \\
1 \cdot 7 \\
2 \cdot 0\end{array}$ & $\begin{array}{l}17 \cdot 6-25 \cdot 6 \\
19 \cdot 2-26 \cdot 2 \\
17 \cdot 6-26 \cdot 0 \\
19 \cdot 4-24 \cdot 2 \\
18 \cdot 4-24 \cdot 0 \\
18 \cdot 4-24 \cdot 4 \\
17 \cdot 1-23 \cdot 5\end{array}$ & $\begin{array}{l}21 \cdot 1 \\
22 \cdot 0 \\
21 \cdot 9 \\
22 \cdot 9 \\
22 \cdot 8 \\
23 \cdot 0 \\
23 \cdot 3\end{array}$ & $\begin{array}{l}1 \cdot 8 \\
1 \cdot 3 \\
1 \cdot 6 \\
1 \cdot 7 \\
1 \cdot 6 \\
1 \cdot 6 \\
2 \cdot 1\end{array}$ & $\begin{array}{l}17 \cdot 7-24 \cdot 6 \\
19 \cdot 7-24 \cdot 6 \\
19 \cdot 7-25 \cdot 7 \\
21 \cdot 3-27 \cdot 2 \\
20 \cdot 5-26 \cdot 8 \\
19 \cdot 9-25 \cdot 5 \\
20 \cdot 0-26 \cdot 0\end{array}$ \\
\hline \multicolumn{2}{|c|}{ Actual $\mathrm{HCO}_{3}^{-}(\mathrm{mEq} / \mathrm{l})}$. & $\cdots$ & $\cdots$ & $\begin{array}{r}2 \\
4 \\
6 \\
12 \\
24 \\
48 \\
72\end{array}$ & $\begin{array}{l}21 \cdot 8 \\
22 \cdot 9 \\
23 \cdot 3 \\
21 \cdot 7 \\
20 \cdot 8 \\
21 \cdot 6 \\
20 \cdot 6\end{array}$ & $\begin{array}{l}2 \cdot 9 \\
3 \cdot 7 \\
4 \cdot 3 \\
2 \cdot 6 \\
1 \cdot 9 \\
1 \cdot 6 \\
2 \cdot 7\end{array}$ & $\begin{array}{l}17 \cdot 0-26 \cdot 1 \\
17 \cdot 0-30 \cdot 5 \\
15 \cdot 4-30 \cdot 5 \\
17 \cdot 2-26 \cdot 0 \\
16 \cdot 2-24 \cdot 6 \\
17 \cdot 6-24 \cdot 6 \\
14 \cdot 4-23 \cdot 6\end{array}$ & $\begin{array}{l}21 \cdot 3 \\
21 \cdot 4 \\
21 \cdot 4 \\
22 \cdot 1 \\
21 \cdot 7 \\
21 \cdot 3 \\
22 \cdot 2\end{array}$ & $\begin{array}{l}4 \cdot 3 \\
1 \cdot 4 \\
1 \cdot 9 \\
2 \cdot 0 \\
1 \cdot 9 \\
2 \cdot 0 \\
3 \cdot 1\end{array}$ & $\begin{array}{l}18 \cdot 5-27 \cdot 5 \\
18 \cdot 0-23 \cdot 4 \\
17 \cdot 5-24 \cdot 7 \\
19 \cdot 5-27 \cdot 4 \\
18 \cdot 1-26 \cdot 4 \\
19 \cdot 4-26 \cdot 0 \\
17 \cdot 0-28 \cdot 0\end{array}$ \\
\hline
\end{tabular}

\section{Results}

The values for $p \mathrm{H}, \mathrm{PCO}_{2}$, base excess, buffer base, standard bicarbonate, and actual bicarbonate at the times given above are summarized in Table 1.

The results of other authors are set out in Table 2. To enable a more direct comparison between the various studies, the relevant base excess has been calculated where not given. Fischer and Toussaint (1963) did not warm the foot before sampling, so that their figures are not strictly comparable. When allowances are made for different ages, methods of sampling, technique of determination, and calculations, the measurements of the present study approximate to those of other authors.

In Table 3 the comparative figures in premature infants with sustained respiratory rates (RR) over $60 / \mathrm{min}$. (neonatal tachypnoea) and $\mathrm{RR}<60$ are set out. Neonatal tachypnoea is defined as a sustained
RR $>60$ for more than 3 hours in the absence of other signs of respiratory distress. 7 premature and 3 full-term infants fulfilled these criteria. Of the 7 prematures, 6 still had a RR $>60$ at 12 hours. There was no significant difference between the two groups $(p>0.05)$. This confirms the findings of Branning (1942) and Prod'hom et al. (1964). Nor could any correlation be found in the full-term infants between the RR and the acid-base values. Both groups had a similar distribution of acid-base status.

Acid-base Distribution. One of the objects was to study the acid-base changes in the same infant with relation to time. The changing patterns are demonstrated in Tables 4 and 5. We have again used the normal adult values and acid-base distribution as the basis of grouping (Siggaard Andersen, 
TABLE 2 ACID-BASE VALUES REPORTED BY VARIOUS INVESTIGATORS

\begin{tabular}{|c|c|c|c|c|c|c|c|c|c|}
\hline Author & & Infants & Age & Blood & $p \mathrm{H}$ & $\underset{(\mathrm{mm} . \mathrm{Hg})}{\mathrm{PCO}_{2}}$ & $\begin{array}{c}\text { 'BE'* } \\
(\mathrm{mEq} / \mathrm{l} .)\end{array}$ & $\underset{(\mathrm{mEq} / \mathrm{l} .)}{\text { Total } \mathrm{CO}_{2}}$ & $\underset{(\mathrm{mEq} / \mathrm{l} .)}{\mathrm{BB}+}$ \\
\hline $\begin{array}{l}\text { Reardon et al. (1950) } \\
\text { Graham and Wilson (1954) }\end{array}$ & $\cdots$ & $\begin{array}{l}1 \cdot 1-2 \cdot 3 \mathrm{~kg} \\
>2 \cdot 4 \mathrm{~kg}\end{array}$ & $\begin{array}{l}\text { 1-65 day } \\
4-24 \mathrm{hr} \text {. }\end{array}$ & $\begin{array}{l}\text { Arterial } \\
\text { Capillary }\end{array}$ & $\begin{array}{l}7 \cdot 31 \\
7 \cdot 43\end{array}$ & $\begin{array}{l}39 \cdot 0 \\
30 \cdot 0\end{array}$ & $\begin{array}{l}-6 \cdot 0 \\
-2 \cdot 8\end{array}$ & $\begin{array}{l}20 \cdot 2 \\
19 \cdot 9\end{array}$ & \\
\hline Weisbrot et al. (1958) . & . & $>2.5 \mathrm{~kg}$ & $\begin{array}{c}3 \mathrm{hr} \text {. } \\
24 \mathrm{hr} \text {. }\end{array}$ & $\begin{array}{l}\text { Arterial } \\
\text { Arterial }\end{array}$ & $\begin{array}{l}7 \cdot 34 \\
7 \cdot 408\end{array}$ & $\begin{array}{l}38 \cdot 3 \\
33 \cdot 6\end{array}$ & $\begin{array}{l}-4 \cdot 6 \\
-2 \cdot 5\end{array}$ & $\begin{array}{l}21 \cdot 87 \\
21 \cdot 38\end{array}$ & $\begin{array}{l}43 \cdot 94 \\
44 \cdot 74\end{array}$ \\
\hline Reardon et al. (1960) .. & $\ldots$ & $\begin{array}{l}\text { Full-term } \\
\text { Premature }\end{array}$ & $\begin{array}{l}1 \mathrm{hr} . \\
4 \mathrm{hr} . \\
24 \mathrm{hr} . \\
48 \mathrm{hr} . \\
72 \mathrm{hr} . \\
96 \mathrm{hr} . \\
48 \mathrm{hr} .\end{array}$ & $\begin{array}{l}\text { Arterial } \\
\text { Arterial } \\
\text { Arterial } \\
\text { Arterial } \\
\text { Arterial } \\
\text { Arterial } \\
\text { Arterial }\end{array}$ & $\begin{array}{l}7 \cdot 30 \\
7 \cdot 33 \\
7 \cdot 38 \\
7 \cdot 39 \\
7 \cdot 38 \\
7 \cdot 39 \\
7 \cdot 31\end{array}$ & $\begin{array}{l}39 \cdot 1 \\
37 \cdot 7 \\
33 \cdot 4 \\
34 \cdot 1 \\
34 \cdot 8 \\
36 \cdot 4 \\
38 \cdot 9\end{array}$ & $\begin{array}{l}-7 \cdot 0 \\
-5 \cdot 7 \\
-4 \cdot 2 \\
-3 \cdot 4 \\
-3 \cdot 6 \\
-2 \cdot 3 \\
-6 \cdot 3\end{array}$ & $\begin{array}{l}20 \cdot 0 \\
20 \cdot 7 \\
20 \cdot 5 \\
21 \cdot 1 \\
21 \cdot 5 \\
22 \cdot 5 \\
20 \cdot 3\end{array}$ & $\begin{array}{l}42 \cdot 3 \\
44 \cdot 3 \\
44 \cdot 7 \\
45 \cdot 0 \\
44 \cdot 8 \\
46 \cdot 0\end{array}$ \\
\hline Fischer and Toussaint (1963) & $\ldots$ & $>2 \cdot 1 \mathrm{~kg}$ & $24 \mathrm{hr}$. & Capillary & $7 \cdot 28$ & $35 \cdot 5$ & $-8 \cdot 8$ & & \\
\hline Prod'hom et al. (1964) & . & $\mathrm{IDM}_{+}^{+}$ & $\begin{array}{l}4 \mathrm{hr} . \\
24 \mathrm{hr} \text {. }\end{array}$ & $\begin{array}{l}\text { Arterial } \\
\text { Arterial }\end{array}$ & $\begin{array}{l}7 \cdot 37 \\
7 \cdot 43\end{array}$ & $\begin{array}{l}40 \cdot 0 \\
36 \cdot 0\end{array}$ & $-1 \cdot 9$ & $\begin{array}{l}24 \cdot 7 \\
23 \cdot 8\end{array}$ & \\
\hline Kildeberg (1964a) & . & $\begin{array}{l}<2.5 \mathrm{~kg} . \\
\text { Full-term }\end{array}$ & $\begin{array}{l}0-7 \text { day } \\
0-7 \text { day }\end{array}$ & $\begin{array}{l}\text { Capillary } \\
\text { Capillary }\end{array}$ & $\begin{array}{l}7 \cdot 37 \\
7 \cdot 40\end{array}$ & $\begin{array}{l}37 \cdot 7 \\
35 \cdot 4\end{array}$ & $\begin{array}{l}-2 \cdot 6 \\
-1 \cdot 94\end{array}$ & $\begin{array}{l}22 \cdot 4 \\
22 \cdot 3\end{array}$ & $\begin{array}{l}46 \cdot 8 \\
49 \cdot 0\end{array}$ \\
\hline
\end{tabular}

* Base excess. $\quad+$ Buffer base. $\quad \ddagger$ Infants of diabetic mothers

TABLE 3

COMPARISON OF 15 PREMATURE INFANTS WITH AND WITHOUT NEONATAL TACHYPNOEA

\begin{tabular}{|c|c|c|c|c|c|c|c|}
\hline \multirow{2}{*}{ Age (hr.) } & \multicolumn{4}{|c|}{7 Cases With Tachypnoea } & \multicolumn{3}{|c|}{8 Cases Without Tachypnoea } \\
\hline & $\begin{array}{l}\text { No. with } \\
\text { RR } 60\end{array}$ & $p \mathbf{H}$ & $\underset{(\mathrm{mm} . \mathrm{Hg})}{\mathrm{PCO}_{2}}$ & $\begin{array}{c}\mathrm{BE}^{*} \\
(\mathrm{mEq} / 1 .)\end{array}$ & $p \mathrm{H}$ & $\underset{(\mathrm{mm} . \mathrm{Hg})}{\mathrm{PCO}_{2}}$ & $\begin{array}{c}\mathrm{BE}^{*} \\
(\mathrm{mEq} / \mathrm{l} .)\end{array}$ \\
\hline $\begin{array}{r}2 \\
4 \\
6 \\
12\end{array}$ & $\begin{array}{l}7 \\
7 \\
6 \\
6\end{array}$ & $\begin{array}{l}7 \cdot 34 \\
7 \cdot 34 \\
7 \cdot 35 \\
7 \cdot 37\end{array}$ & $\begin{array}{l}43 \cdot 2 \\
40 \cdot 4 \\
45 \cdot 8 \\
38 \cdot 7\end{array}$ & $\begin{array}{l}3 \cdot 2 \\
-2.2 \\
-1.1 \\
-2.9\end{array}$ & $\begin{array}{l}7 \cdot 30 \\
7 \cdot 35 \\
7 \cdot 36 \\
7 \cdot 37\end{array}$ & $\begin{array}{l}42 \cdot 8 \\
43 \cdot 2 \\
42 \cdot 1 \\
39 \cdot 5\end{array}$ & $\begin{array}{l}-4 \cdot 1 \\
-2 \cdot 2 \\
-2 \cdot 2 \\
-2 \cdot 1\end{array}$ \\
\hline
\end{tabular}

* Base excess.

TABLE 4 COURSE OF ACID-BASE STATUS IN 16 FULL-TERM INFANTS DURING FIRST 3 DAYS OF LIFE

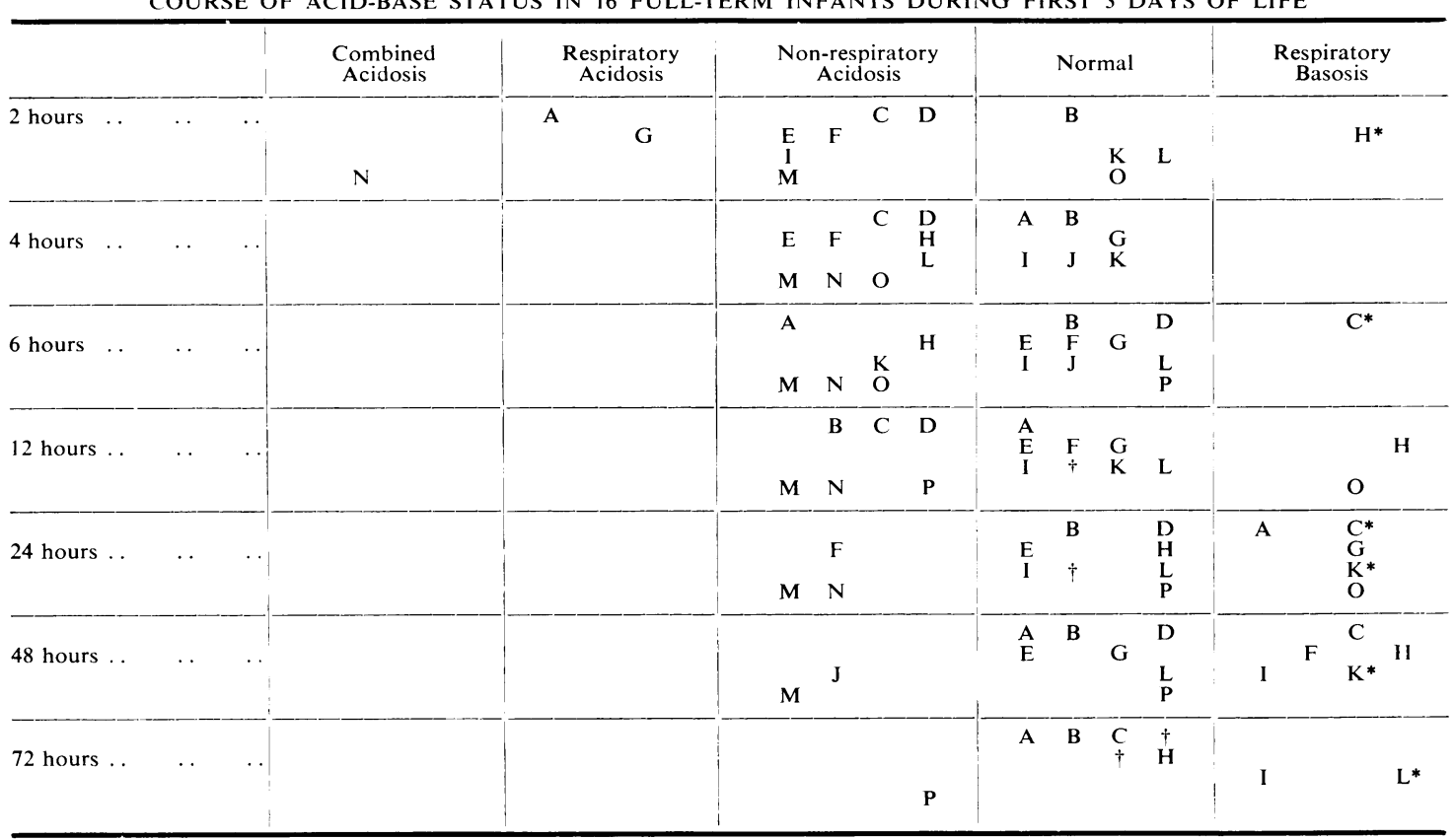

* Crying. $\quad+$ Non-respiratory basosis. 
TABLE 5

COURSE OF ACID-BASE STATUS IN 16 PREMATURE INFANTS DURING FIRST 3 DAYS OF LIFE

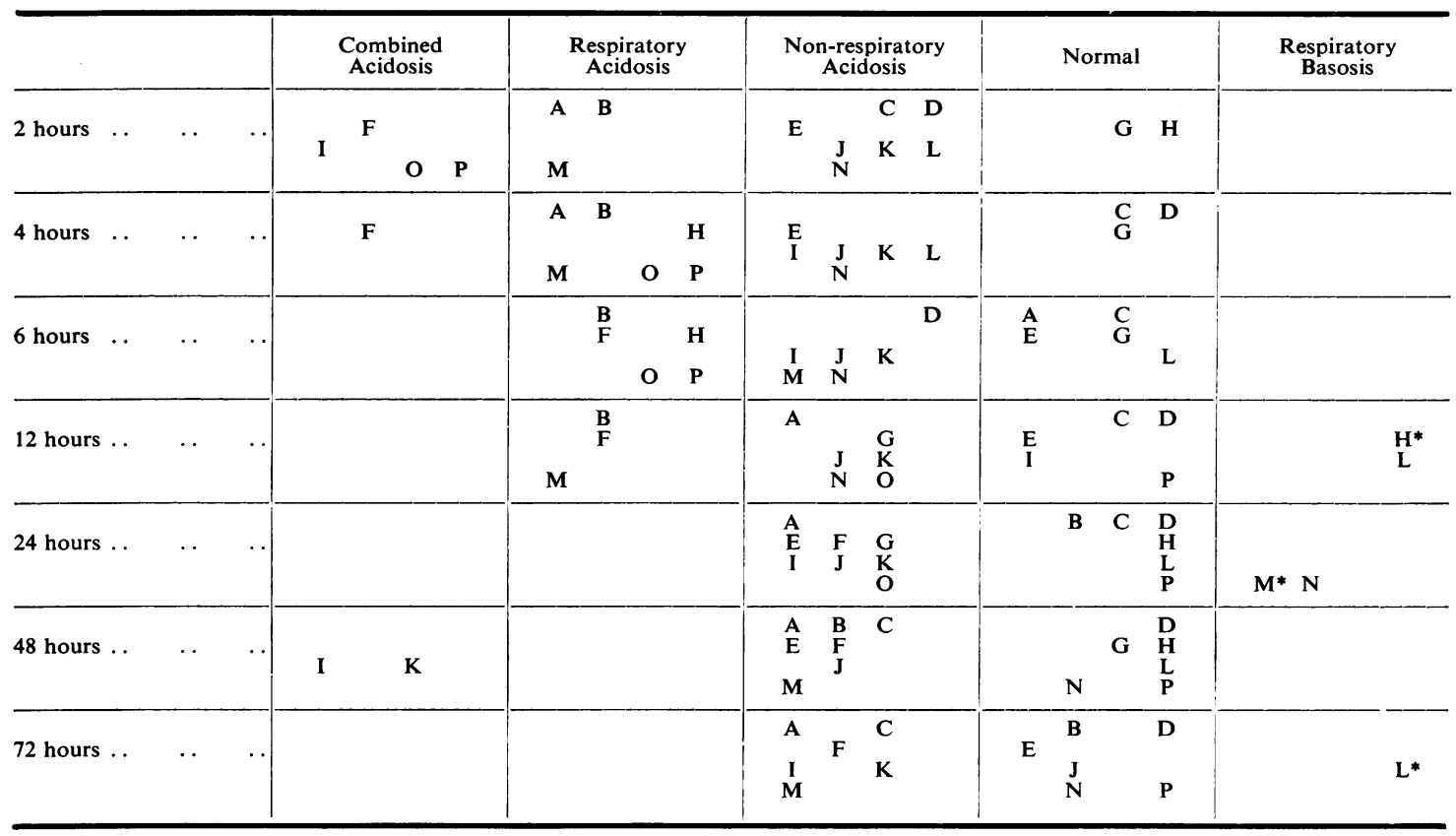

* Crying.

1963). Each infant was designated by a letter of the alphabet and charted in the same position at each successive reading according to the acid-base status at that moment. It is, therefore, possible to follow individual infants as well as the over-all pattern. It is of interest to note that 9 of the 12 infants who were crying at the time of blood sampling were in respiratory basosis. These readings were not excluded from the study because it is not always possible to prevent crying in newborn infants, which can be regarded as part of the normal pattern.

(a) Full-term Infants. In this group, the striking finding is the normality of their acid-base status. Infants are born with a combined respiratory and non-respiratory acidosis. The full-term infants corrected this acidosis very rapidly and no respiratory acidosis persisted beyond 2 hours of life. Even the residual non-respiratory acidosis is of a minor degree and is virtually absent at 72 hours. These results are in accordance with Graham and Wilson (1954), Prod'hom et al. (1964), and Kildeberg (1964a). Weisbrot et al. (1958) and Reardon et al. (1960) found a greater degree of non-respiratory acidosis. The normal range forms the largest over-all group in Table 4. Seven infants had a respiratory basosis at some stage, usually after 24 hours. Reardon et al. (1960) found this in $18 \%$ of their infants. 3 infants were in mild non-respiratory basosis. Throughout the 72 hours the same infant tended to follow the same pattern, either of normality or of mild nonrespiratory acidosis. This stability was very different from the premature group.

(b) Premature Infants. Some of the essential differences between premature and full-term infants are seen in Table 5. The wider scatter and greater degree of individual variation is in agreement with the findings of Reardon et al. (1950). Respiratory acidosis is much more persistent, and apparently healthy prematures often have quite high levels of $\mathrm{PCO}_{2}$. Kildeberg (1964a) has remarked on the same finding. Non-respiratory acidosis forms the largest single group, which is in accordance with all other published figures. At 72 hours there were still as many in the non-respiratory acidosis group as in the normal range. Only 2 premature infants showed a spontaneous respiratory basosis. Reardon et al. (1950) found no prematures with respiratory basosis. The two infants at 48 hours with combined acidosis underline the acid-base instability of the premature infant (Reardon et al., 1950). 


\section{Discussion}

Prematurity. Because of the greater scatter of acid-base disturbances among premature infants, it would be of value in future to assess such variation according to gestational age. It is widely accepted that birth weight alone is not a reliable index of premature birth (Gruenwald, 1964). Some of our infants may well have been of low birth weight for age. Reardon et al. (1950), in their group of prematures between 1 and 65 days, found no statistical correlation of acid-base values to birth weight or age of sampling. It may well be that the greater degree of non-respiratory acidosis reported by them was due to the lower birth weights. On the other hand, their group would include infants with late non-respiratory acidosis developing after the first few weeks of life (Kildeberg, 1964b). In the present study the differences between the two groups are striking enough to indicate different populations.

The lowest mean base deficit was found at 6 hours corresponding to the highest standard bicarbonate levels. Whereas the standard bicarbonate levels in the full-term infants rose steadily with increasing age, those of the prematures appeared to fall again. This would be in keeping with their greater tendency to non-respiratory acidosis.

Neonatal Tachypnoea. Branning (1942) studied a group of acidotic (hyperpnoea) infants and found no difference between their acid-base status and that of 'normal' infants. Prod'hom et al. (1964) in their elegant study on infants of diabetic mothers (IDM), came to the conclusion that there was no difference in the $p \mathrm{H}, \mathrm{PaCO}_{2}$, and total ventilation between infants with RR of over $60 / \mathrm{min}$. and those with a lower rate. These infants represent an extreme of the normal range with altered dead space/tidal volume ratios. The phenomenon of neonatal tachypnoea is more common in premature infants and may represent a form of structural immaturity. We agree entirely with other workers that a high $\mathbf{R R}$ alone is not indicative of respiratory distress. Our clinical experience with neonatal tachypnoea is to be the subject of a future publication.

Carbon Dioxide Tension. Contrary to the experience of others (Reardon et al., 1960), little difference was found in this series in either the $\mathrm{PCO}_{2}$ or $p \mathrm{H}$ of the premature and full-term groups at 2 hours. At 4 hours the premature infants showed a greater degree of hypoventilation. Our figures for $\mathrm{PCO}_{2}$ correspond more closely to those of Prod'hom et al. (1964) than they do to other series, but this is probably the reflection of determination at different ages. Reardon et al. (1960) recorded their lowest $\mathrm{PCO}_{2}$ values at 24 hours, and this corresponds to our premature group. The lowest value for full-term infants in the present series was found at 48 hours.

In all studies, the lowered $\mathrm{PCO}_{2}$ of the full-term newborn and, to a lesser extent, premature infants is confirmed. The possible causes for this are discussed by Weisbrot et al. (1958). It is apparent from all the published data that the acid-base nomograms for adults are not entirely acceptable for the newborn and that allowance should be made for this (Oliver et al., 1961; Prod'hom et al., 1964). Sufficient data are, however, not available to define and delineate clearly the normal range of $p \mathrm{H}, \mathrm{PCO}_{2}$, base excess, and standard bicarbonate in the newborn premature and full-term infant.

Caesarean Section. There were not sufficient numbers in the present series to compare the acidbase status of infants delivered by different routes.

\section{Summary}

Serial acid-base values for 17 premature and 16 full-term infants during the first 72 hours of life are presented. There is good agreement between the present study and comparable published data.

Premature infants have a more prolonged respiratory acidosis and a greater tendency towards nonrespiratory acidosis. They exhibit a more variable and unstable acid-base pattern. No published reports of serial acid-base studies in premature infants are available for comparison.

Full-term infants are found to be in relatively normal and stable acid-base status; $37 \%$ have respiratory basosis at some time.

No correlation is found between neonatal tachypnoea (sustained respiratory rate $>60$ ) and the acid-base status.

We wish to thank the Matron and staff of the Peninsula Maternity Hospital for their assistance and interest; Dr. A. W. Falconer, Medical Superintendent of the Peninsula Maternity Hospital for permission to publish; the Council for Scientific and Industrial Research for financial assistance; the Teaching Hospitals Staff Research Fund and the C. L. Herman Bequest Award for equipment used; Professor F. J. Ford for helpful criticism; and Mrs. O. M. Cartwright for her help in the preparation of this paper.

\section{REFERENCES}

Branning, W. S. (1942). The acid-base balance of premature infants. J. clin. Invest., 21, 101.

Fischer, W. M., and Toussaint, W. (1963). Über den Säure-BaseHaushalt beim Neugeborenen: Untersuchungen in den ersten Lebensminuten. Arch. Gynäk., 199, 182.

Gambino, S.R.(1961). Collection of capillary blood for simultaneous determinations of arterial $\mathrm{pH}, \mathrm{CO}_{2}$ content, $\mathrm{pCO}_{2}$, and oxygen saturation. Amer. J. clin. Path., 35, 175.

Gandy, G., Grann. L., Cunningham, N., Adamsons, K., Jr., and James, L. S. (1964). The validity of $\mathrm{pH}$ and $\mathrm{PCO}_{2}$ measurements in capillary samples in sick and healthy newborn infants. Pediatrics, 34, 192. 
Graham, B. D., and Wilson, J. L. (1954). Chemical control of respiration in newborn infants. Amer. J. Dis. Child., 87, 287.

Gruenwald, P. (1964). Infants of low birth weight among 5,000 deliveries. Pediatrics, 34, 157.

Kildeberg, P. (1964a). Disturbances of hydrogen ion balance occurring in premature infants. I. Early types of acidosis. Acta paediat. (Uppsala), 53, 505.

- - (1964b). Disturbance of hydrogen ion balance occurring in premature infants. II. Late metabolic acidosis. ibid., 53, 517.

Oliver, T. K., Jr., Demis, J. A., and Bates, G. D. (1961). Serial blood-gas tensions and acid-base balance during the first hour of life in human infants. ibid., 50, 346.

Prod'hom, L. S., Levison, H., Cherry, R. B., Drorbaugh, J. E., Hubbell, J. P., Jr., and Smith, C. A. (1964). Adjustment of ventilation, intrapulmonary gas exchange, and acid-base balance during the first day of life. Pediatrics, 33, 682 .
Reardon, H. S., Baumann, M. L., and Haddad, E. J. (1960). Chemical stimuli of respiration in the early neonatal period. J. Pediat., 57, 151.

—, Graham, B. D., Wilson, J. L., Baumann, M. L., Tsao, M. U., and Murayama, M. (1950). Studies of acid base equilibrium in premature infants. Pediatrics, 6, 753.

Rosenthal, T. B. (1948). The effect of temperature on the $p H$ of blood and plasma in vitro. J. biol. Chem., 173, 25.

Siggaard Andersen, O. (1963). The acid-base status of the blood. Scand. J. clin. Lab. Invest.. 15, Suppl. 70.

—, Engel, K., Jørgensen, K., and Astrup, P. (1960). A micro method for determination of $\mathrm{pH}$, carbon dioxide tension, base excess and standard bicarbonate in capillary blood. ibid., 12, 172.

Weisbrot, I. M., James, L. S., Prince, C. E., Holaday, D. A., and Apgar, V. (1958). Acid-base homeostasis of the newborn infant during the first 24 hours of life. J. Pediat., 52, 395. 